October 2007

\title{
Estimating the Cost of Executive Stock Options: Evidence from Switzerland
}


The Author(s):

Prof. Dr. Wolfgang Drobetz

Institut für Unternehmens- und Schiffsfinanzierung

University of Hamburg, DE-20146

wolfgang.drobetz@wiso.uni-hamburg.de

\section{Pascal Pensa}

Department of Finance, University of Basel

CH-4003 Basel, Switzerland,

pascal.pensa@unibas.ch

\section{Markus M. Schmid}

Swiss Institute of Banking and Finance

University of St. Gallen

CH-9000 St. Gallen, Switzerland

markus.schmid@unisg.ch.

A publication oft the Center of Business and Economics (WWZ), University of Basel.

(C) WWZ Forum 2007 and the author(s). Reproduction for other purposes than the personal use needs the permission of the author(s).

\section{Contact:}

WWZ Forum | Petersgraben 51 | CH-4003 Basel | forum-wwz@unibas.ch | www.wwz.unibas.ch 


\title{
Estimating the Cost of Executive Stock Options: Evidence from Switzerland ${ }^{*}$
}

\author{
Wolfgang Drobetz ${ }^{\mathrm{a}}$, Pascal Pensa ${ }^{\mathrm{b}}$, and Markus M. Schmid ${ }^{\mathrm{c}}$
}

\begin{abstract}
It is often argued that Black-Scholes (1973) values overstate the subjective value of stock options granted to risk-averse and under-diversified executives. We construct a "representative" Swiss executive and extend the certainty-equivalence approach presented by Hall and Murphy (2002) to assess the value-cost wedge of executive stock options. Even with low coefficients of relative risk aversion, the discount can be above $50 \%$ compared to the Black-Scholes values. Regression analysis reveals that the equilibrium level of executive compensation is explained by economic determinant variables such as firm size and growth opportunities, whereas the managers' pay-forperformance sensitivity remains largely unexplained. Firms with larger boards of directors pay higher wages, indicating potentially unresolved agency conflicts. We reject the hypothesis that cross-sectional differences in the amount of executive pay vanish when risk-adjusted values are used as the dependent variable.
\end{abstract}

Keywords: Managerial compensation, incentives, executive stock options, option valuation, risk aversion.

JEL classification codes: J33, G13, G32

\footnotetext{
${ }^{a}$ Wolfgang Drobetz, Chair of Corporate Finance and Ship Finance, University of Hamburg, VonMelle-Park 5, 20146 Hamburg, Germany, Phone: +49-40-42838-5506, Mail: wolfgang.drobetz@ wiso.uni-hamburg.de.

${ }^{\mathrm{b}}$ Pascal Pensa, Department of Finance, Wirtschaftswissenschaftliches Zentrum (WWZ), University of Basel, Petersgraben 51, 4003 Basel, Switzerland, Phone: +41-61-267 33 18, Mail: pascal.pensa@unibas.ch.

c Markus M. Schmid, Swiss Institute of Banking and Finance, University of St. Gallen, Rosenbergstrasse 51, 9000 St. Gallen, Switzerland, Phone: +41-71-222 10 94, Mail: markus.schmid@unisg.ch.

* We thank Hélyette Geman, Chris Mallin (the editor), Nicola Safarik, Patrick Wegmann, Heinz Zimmermann, and two anonymous referees for valuable comments. Parts of this research were undertaken while Schmid was a visiting scholar at the Leonard N. Stern School of Business at New York University; he acknowledges financial support from the Freiwillige Akademische Gesellschaft (FAG) and the Swiss National Science Foundation (SNF). All errors remain our responsibility.
} 
Introduction

Not only in the US, but also in Continental Europe finance practice has increasingly used performance-based compensation plans as a means to align the incentives of managers with those of shareholders (e.g., Frey and Osterloh, 2000). In addition to cash bonuses and share allotments, stock options have emerged as a principal component of executive compensation. The arguments supporting the use of executive stock options are manifold. ${ }^{1}$ First, they motivate a firm's executives and attract higher skilled and relatively less risk-averse managers, because these executives will naturally self-select into firms that offer more upside participation. Second, options provide retention incentives through a combination of vesting provisions and long option terms. Third, managers tend to think like owners only by becoming owners. Equity-linked compensation alleviates principal-agent problems between managers and shareholders (Jensen and Meckling, 1976) and provides incentives for executives to take shareholder value maximizing actions. Finally, stock options allow firms to conserve cash and are therefore often regarded as "cheap" from an accounting perspective. However, with the introduction of the IFRS 2 Share-Based Payment standard all stock option grants to employees must be expensed as of January $1,2005 .^{2}$

While the benefits of equity-based compensation are well understood and widely accepted, it is surprising that its costs have received much less attention. After all, as noted by Meulbroek (2001), “[...] if the only result of equity-based compensation were incentive alignments, no natural stopping point would exist: managers’ compensation would be $100 \%$ equity-based.” 3 However, this is clearly not what is observed in practice, and there are several explanations. First, principle-agent models (e.g., Holmström, 1979; Harris and Raviv, 1979) emphasize the efficiency of high-powered incentive contracts, but they also recognize that there is a trade-off between incentives and risk sharing. Second, maybe the current pay-to-performance sensitivity is sufficient to motivate managers towards better performance. ${ }^{4}$ Third, stock options may encourage managers to take excessive risk because increases in the volatility of a company's stock price increase the value of its options. However, managers with lots of at-the-money (or in-the-money) options could become overly cautious, unwilling to jeopardize a large anticipated payoff that will accrue even if the stock price increases at just the T-bill rate. ${ }^{5}$ Finally, there is a potential disparity between the cost of an option grant and the value of that grant to the manager. This value-cost wedge depends on a number of factors, including the degree of diversification in the executive's portfolio, the length of the vesting period of the option, and the risk aversion of the executive. For example, Meulbroek (2001) documents that managers 
in the average NYSE firm value their options at only $70 \%$ of the market value. Hall and Murphy (2002) argue that the growth in risk-adjusted pay has been modest in the US over the last decade, suggesting that executive value has increased far less than company cost.

For options to achieve their stated objectives, the recipients must not be allowed to trade the options or take actions such as short-selling company stock or to otherwise hedge company stock price risk. ${ }^{6}$ While exposure to firm-specific risk is essential for generating managerial incentives, it also imposes economic costs by forcing the recipients to hold a less-than-fully diversified investment portfolio. In fact, executives are forced (by vesting requirements, insider sales restrictions, or board pressure) to hold more company equity than is desirable from a portfolio diversification viewpoint. ${ }^{7}$ Managers' human capital investment in the firm and pension fund holdings that are strongly related to the company's stock further increase their idiosyncratic risk exposure. Overall, there is an inevitable trade-off between incentive alignment and portfolio diversification, and managers will discount the value of their company equity holdings because of this suboptimal risk sharing.

In the first part of this paper, we focus on the common argument that Black-Scholes (1973) values are too high, i.e., when opportunity costs are taken into account, stock options are an expensive way to convey pay. Black-Scholes values provide an estimate of the company's cost of granting an option, but they do not reflect the value of a non-tradable option to risk averse and undiversified executives. We use the Hall-Murphy (2002) certainty-equivalence approach and estimate the deadweight costs for a sample of Swiss firms using stock options as part of their compensation packages. Switzerland is an interesting case to analyze. First, the institutionalization of shareholdings has had a strong effect on the structural changes of the equity market after pension plans became mandatory in the mid-eighties and emerged as the major domestic investment force. Drobetz et al. (2006) report that institutional investors hold almost $50 \%$ of all assets deposited with Swiss banks. On the one hand, institutional investors could promote the efficient use of executive stock options, but on the other hand, they should have incentives to exert control. In fact, their own monitoring activities might substitute for the use of stock option plans as part of the firm's optimal control structure. Second, while the market for corporate control developed slowly during the 1990s (e.g., Loderer and Zgraggen, 1999), there have been serious attempts by Swiss firms to adopt internationally recognized corporate governance principles in recent years. The adoption of executive stock option plans has been a central part of this development in corporate Switzerland (e.g., Beiner et al., 2006). 
In the second part of this paper, we take a closer look at the relationship between the level of executive compensation (including stock options) and the quality of the firm's corporate governance. Most previous work on executive stock options regards managers’ pay arrangements as a (partial) remedy to the agency problem (e.g., Baker, Jensen, and Murphy, 1988; Jensen and Murphy, 1990). The rise in executive compensation can be attributed to the widespread adoption of compensation packages with high-powered incentives since the late 1980s. This view is referred to as the “optimal contracting approach” or “arm’s length approach”. Recently, however, Bebchuk and Fried (2003) have argued that executive compensation should not only be interpreted as an instrument for addressing agency problems, but it should also be viewed as part of the agency problem itself. The “managerial power approach” suggests that managers' pay arrangements are determined both by market forces that provide efficient incentives and assure value-maximizing outcomes and by managerial rent-seeking under weak corporate governance structures, which leads to departures from the optimal outcome and generally benefits managers. ${ }^{8}$ To shed light on this prediction, we explore whether firms with weak control structures in place have greater agency problems and pay a higher compensation to their managers.

Our results indicate that the value-cost wedge can be substantial. For example, even for low relative risk aversion coefficients of 2 and 3, we estimate discounts from the Black-Scholes values of $47 \%$ and $62 \%$, respectively, if all outstanding option packages as of year-end 2002 are included in our analysis. In absolute terms, this translates into deadweight losses of CHF 290 million and CHF 377 million. Our regression results indicate that the equilibrium level of executive pay is explained by economic determinant variables such as firm size and growth opportunities), while board and ownership variables hardly impact the level of total compensation. Nevertheless, firms with larger boards of directors pay higher wages to their executives, indicating potentially unresolved agency problems. In contrast, the pay-for-performance sensitivity is unrelated to both the economic determinant variables as well as to our board and ownership variables. Finally, we reject the hypothesis that the cross-sectional differences in the level of executive pay vanish when risk-adjusted values are employed.

The remainder of the paper is structured as follows. Section 2 briefly introduces the certaintyequivalence framework proposed by Hall and Murphy (2002). The section continues with a data description and documents our estimates for the value-cost wedge. Section 3 starts with 
some general considerations about the relationship between corporate governance and executive compensation and proceeds with our regression results. Section 4 concludes the paper.

\section{Estimating the value-cost wedge of executive stock options}

The Black-Scholes (1973) model or similar option pricing methodologies are appropriate for freely tradable options held by outside investors. However, they are inappropriate for executives who cannot trade or sell their options and are not allowed to hedge specific risks by short-selling company stock. This would eliminate the primary purpose of the option grants, i.e., to align the financial interests of the managers with those of the shareholders. In addition, company executives are inherently undiversified because they hold too much of their physical and human capital in their company. ${ }^{9}$ To assess option values for undiversified executives, we adopt the certainty-equivalence approach presented by Hall and Murphy (2002). Already Lambert et al. (1991) suggest that the standard option pricing models are inappropriate to determine the value of executive stock options. In particular, it is crucial to distinguish between the economic cost to the company (i.e., the amount the company could have received if the option was sold to outside investors) and the economic value to a less-than-fully diversified executive, who can neither trade the option nor otherwise diversify firm-specific risk. ${ }^{10}$

Following Hall and Murphy (2002), we measure the value of a non-tradable option to an undiversified executive as the amount of riskless cash compensation a recipient would exchange for the option. Option values generally depend on six factors: exercise price, stock price, dividend yield, volatility, risk-free rate, and maturity. Hall and Murphy (2002) introduce "executive value lines”, which plot the certainty equivalents of non-tradable options to undiversified executives as a function of the underlying stock price. Their analysis shows that the certaintyequivalent value depends on three additional factors: the manager's risk aversion, his initial wealth, and the fraction of his wealth that is tied to firm performance.

In this section, we estimate the magnitude of the wedge between the subjective value that an executive places on an option and the company cost of the same option for a sample of Swiss firms. Given the peculiarities of Swiss disclosure rules, we adjust the Hall-Murphy framework. We describe the disclosure rules and our data set in section 2.1, and proceed by explaining our model extensions in section 2.2. The empirical results are presented in section 2.3. 


\subsection{Disclosure rules and data sample}

Recently, many European countries have adopted new standards, rules, or codes of best practice to establish guidelines for listed companies and to improve the overall level of corporate governance. In Switzerland the "Directive on Information Relating to Corporate Governance” of the Swiss Exchange and the accompanying "Swiss Code of Best Practice" became effective as of July 1, 2002. This new set of rules is assumed to reflect best practice, but they are not legally binding and require disclosure on a comply-or-explain basis. Section 5 of the directive recommends that companies disclose information on compensation and shareholdings. Generally, they ought to "[...] disclose the total of all compensation such as honorariums, salaries, credits, bonuses and benefits in kind that [...] directly and indirectly benefited members of the board of directors and/or the management board." 11 In what follows, we refer to the members of the board of directors and the management board simply as "executives". In addition to the total of all compensation, companies are urged to provide more detailed information and disclose the number of shares that are allotted to and held by each executive. Companies are also urged to provide an overview of the options on shares that are held by the group of executives, including information about the allotment year, the vesting period, the subscription ratio and the exercise price. The directive does not require individualized information, but it merely specifies that firms must report ownership and compensation figures on an aggregate level for executives and executive directors on the board as well as for non-executive directors. Lacking individualized information about compensation structures, we study a "representative" Swiss executive (section 2.2 below). ${ }^{12}$

We target all 235 companies of the Swiss Performance Index (excluding investment companies). For the sample period, complete datasets are available for only 173 listed firms. ${ }^{13}$ Based on the annual reports for the reporting year 2002, we find that 80 firms explicitly state that they use stock options, and 70 firms report that they generally do not allot stock options. The disclosure of the remaining 23 firms is incomplete, and these firms are omitted. Out of the 80 option granting firms, there are 2 firms that issue options where the underlying stock is traded in Swiss francs, but the strike price is in US dollars. ${ }^{14}$ The final sample consists of 78 firms with a total of 333 outstanding option packages, where 98 packages were granted in 2002 (i.e., the first reporting year during which the new disclosure rules applied), and the remaining 235 outstanding packages were allotted already before 2002. Compensation data were gathered from the annual reports, and all other data were obtained from the Datastream database. 


\subsection{Model adjustments}

To calculate the value-cost wedge, we estimate what Hall and Murphy (2002) call the "riskadjusted pay”. To put their framework at work with Swiss data, we start with an assumption about the initial wealth of an executive, denoted as $w$. Lacking individualized compensation data, we define the risk-free wealth of a company's executive as follows:

$$
w=\max \left(R \cdot 5^{\prime} 000^{\prime} 000,4 \cdot C a s h\right),
$$

where $R$ denotes the number of firm executives eligible for equity-based compensation, and Cash is the amount of total cash compensation (including cash bonuses and other cash components) they receive. This assumption implies that, on average, an executive's safe wealth is assumed to be the greater of CHF 5 million or four times total cash compensation. ${ }^{15}$ Hall and Murphy’s (2002) approach can be generalized to incorporate several option packages. In addition to non-firm related wealth of $w$, assume that the executive holds $s$ shares of company stock and is granted $n$ options to buy $n$ shares of stock at exercise price $X$ in $T$ years. If the executive's initial wealth is invested at the risk-free rate, $r_{f}$, and the stock price at maturity is $P_{T}$, his end-of-period wealth is:

$$
W_{T} \equiv w^{-R}\left(1+r_{f}\right)^{T}+s \cdot P_{T}^{-R}+\sum n_{j}^{-R} \cdot \max \left(0, P_{T}-X_{j}\right)+\sum n_{i}^{-R} \cdot \max \left(0, P_{T}-X_{i}\right),
$$

where the summation terms allow for different option packages granted before 2002 (type $j$ ) and in 2002 (type $i$ ), respectively. Comparing the notation in equation (2) to that in Hall and Murphy (2002), there are two differences. First, lacking individualized compensation data, we divide by the number of executives eligible for equity-based compensation, $R$, to obtain average figures. This representative agent approach clearly underestimates the deadweight loss for the CEO of a company, who is supposedly the best paid company executive. Nevertheless, the bias should be mitigated given that we observe that stock option allotments are much more evenly distributed among the executives in our Swiss sample than in the US. Second, we cannot discount cash bonuses to account for their implied risk because firms are not required to disclose separate information. However, note that the initial wealth, $w$, in equation (1) already incorporates total cash compensation (including cash bonuses and other cash components).

If, instead of the option, the manager was awarded $V$ in cash (to be compounded at the riskfree rate), his wealth at time $T$ is defined as: 
(3)

$$
W_{T}^{V} \equiv(w+V)^{-R} \cdot\left(1+r_{f}\right)^{T}+s \cdot P_{T}^{-R}+\sum n_{j}^{-R} \cdot \max \left(0, P_{T}-X_{j}\right)
$$

The specification in equation (3) still contains all options granted before 2002 (type $j$ ) and would be appropriate if we were to distinguish between different years of allotment and only evaluate the value-cost wedge for options granted during the reporting year 2002. However, to exploit our relatively small sample size, we analyze all 333 outstanding option packages as of year-end 2002 separately. Therefore, we compute the certainty equivalent, $V$, for each option package (both type $i$ and $j$ ) by taking the average executive's wealth at time $T$ as:

$$
W_{T}^{V} \equiv(w+V)^{-R} \cdot\left(1+r_{f}\right)^{T}+s \cdot P_{T}^{-R}
$$

As described in Hall and Murphy (2002), we assume that an executive's utility over wealth is $U(W)$ with constant relative risk aversion. We measure the value of a non-tradable option to an undiversified executive as the amount of riskless cash compensation the recipient would exchange for the option. An executive's risk adjusted compensation is the certainty equivalent $V$ that equates the expected utilities in equation (3) in Hall and Murphy (2002). ${ }^{16}$ We further assume that the Capital Asset Pricing Model (CAPM) holds. The distribution of stock prices in $T$ years is lognormal with return volatility $\sigma$ and expected return, $\mu$, as given by:

$$
\mu=E(r)=\left(r_{f}+\beta \cdot\left(r_{m}-r_{f}\right)-\sigma^{2} / 2\right) \cdot T
$$

Based on the historical properties of the Swiss stock market (Drobetz, 2001), we assume that $r_{f}=4.5 \%$ and $r_{m}-r_{f}=5.5 \%$ (equity risk premium). We use firm-specific volatilities and betas, where the former are computed using each firm's monthly stock returns over the period from January 1999 to December 2002, and the latter are based on market model regressions involving the Swiss Performance Index (SPI) over the same time period. We further assume that a firm maintains the average 1999 to 2002 annual dividend yield until the options expire.

\subsection{Risk-adjusted pay in Switzerland}

Table 1 presents descriptive statistics of the compensation packages for our sample firms during the reporting year 2002. All figures are market values, and they have to be interpreted as costs incurred by the firms and not as values for executives or directors. The average executive compensation in our sample for 2002 is CHF 753’975. The distribution is heavily skewed to the right, as indicated by the much lower median compensation (CHF 410'713) as well as 
the minimum and the maximum compensation values. ${ }^{17}$ Roughly 68\% (CHF 511'392) of the average total compensation are paid out in cash. As mentioned earlier, cash includes cash compensation, cash bonuses and other compensation components paid out in cash. Another 10\% (CHF 74'152) are paid in the form of company stock. Company stock is valued at 2002 year-end prices. The remaining 22\% (CHF 168'431) of the compensation were paid out by granting stock options. Stock options are valued using the Black-Scholes (1973) option pricing formula and year-end 2002 stock prices.

[Insert table 1 here]

The figures in table 1 represent the cost of a compensation package from a company perspective. A value-cost wedge arises if the recipient of the option cannot trade nor hedge against adverse stock price movements and is less-than-optimally diversified from a portfolio diversification viewpoint. Figure 1 shows the average Black-Scholes (market) values and the average risk-adjusted values of the option package for the "representative” Swiss executive, depending on the year of grant (either in 2002 or before) and his coefficient of relative risk aversion, denoted as $\rho$. As expected, the executive value of the average option packages decreases strictly with risk aversion. Looking at all option packages together (granted in 2002 or before), even with a moderate risk aversion of $\rho=2$, the subjective value of an option package decreases by 49\% (from CHF 482'878 to CHF 244’002), on average. Considering only option packages allotted in 2002, the value decrease amounts to $41 \%$. An increase in the coefficient of relative risk aversion to $\rho=3$ leads to subjective value losses of $62 \%$ and $57 \%$ for all option packages and those granted in 2002, respectively. With a fairly high coefficient of relative risk aversion of $\rho=10$, the option package becomes almost worthless - compared to the Black-Scholes value, an executive discounts the options by $89 \%$. In this case, it is hard to argue that there are any incentive alignment effects remaining at all. However, because stock options, on average, make up a much smaller proportion of total compensation than cash, the decrease in executive value of total pay is less pronounced. All else equal, total compensation decreases by $9.2 \%$ and $12.7 \%$ with $\rho=2$ and $\rho=3$, respectively. This implies that the relative fraction of stock options as part of the total compensation package decreases from $22 \%$ using Black-Scholes values to $14.5 \%$ (with $\rho=2$ ) or $11.1 \%$ (with $\rho=3$ ) in the certainty-equivalent framework.

[Insert figure 1 here] 
Instead of looking at the "representative" Swiss executive, we can also asses the aggregate deadweight costs incurred by the allotment of executive stock options. Figure 2 shows the aggregate Black-Scholes and risk-adjusted option values, obtained by summing up our previous results over all 98 option packages allotted in 2002 by our 78 sample firms. Note that this approach is crude at best and ignores personal cross-linkages that exist between the companies’ boards. Such cross-linkages are the rule rather than the exception in Switzerland, and therefore the following numbers should only be taken as approximations. The direction of this bias is hard to predict. On the one hand, more options should imply lower value-cost ratios. On the other hand, a manager who serves on the board of several companies may also experience diversification benefits. Using Black-Scholes values, the total aggregate compensation for 2002 amounts to roughly CHF 947 million. From this total aggregate, 64\% were paid out in cash (including cash bonuses and all other cash components), 12\% through stock allotments, and $24 \%$ in stock options. Adjusting the option component, but all else equal, with a risk aversion of with $\rho=2$ and $\rho=3$ the risk-adjusted total compensation reduces to CHF 858 million and CHF 820 million, respectively.

\section{[Insert figures 2 and 3 here]}

Figure 3 shows the Black-Scholes value of all outstanding option packages (granted in 2002 and before) and compares it with the risk-adjusted values. The Black-Scholes value of all outstanding option packages as of year-end 2002 amounts to CHF 612 million. Assuming risk aversion coefficients of $\rho=2$ and $\rho=3$, the reductions are $47 \%$ and $62 \%$, respectively. These risk-adjustments imply aggregate deadweight losses of CHF 290 million (for $\rho=2$ ) and CHF 377 million (for $\rho=3$ ). Clearly, while these figures appear large in absolute values, they appear small when put into a relevant context. For example, they account for merely $0.05 \%$ and 0.07\% of aggregate sample market capitalization (as of year-end 2002), respectively. Looking only at options granted in 2002, the reductions are 36\% (for $\rho=2$ ) and 56\% (for $\rho=3$ ), implying aggregate deadweight losses of CHF 88 million and CHF 126 million, translating into $0.01 \%$ and $0.02 \%$ of aggregate sample market capitalization, respectively. 
Corporate governance and executive compensation

\subsection{Methodological approach and variable description}

In spite of the value-cost wedge, executive stock options are widely considered as a means to alleviate the agency problem in public companies. In addition to measuring the true costs of executive stock options, therefore, a closely related question is whether firms allot options efficiently, given their operative environment and corporate control structure. In their managerial power approach, Bebchuk and Fried (2003) suggest that executive pay will be higher and/or less sensitive to performance when managers have more power and are able to extract rents. Based on this notion, in this section we explore whether firms with weak corporate governance structures have greater agency problems and pay their managers a higher compensation.

As in Core et al. (1999), we use total executive compensation as a metric for assessing the effectiveness of corporate governance and assume that, among other corporate control mechanisms, managers' power depends on board and ownership structures. A caveat is that corporate governance structures and managerial incentive compensation arise simultaneously and endogenously. ${ }^{18}$ We start with the null hypothesis that observed ownership and board structures induce optimal contracting and firm performance. Shareholders must choose both the firm's corporate governance structure and the executive compensation contracts to maximize firm value, given the firm's operative environment and the reservation wage for a manager of a given quality. However, costs and benefits of corporate governance mechanism differ across firms, and therefore firms will deliberately vary in adopting these mechanisms. For example, Smith and Watts (1992) claim that larger firms and firms with greater investment opportunities are more complex operations and are more likely to demand higher-quality managers with higher equilibrium wages. If the observed ownership and board structures bring about optimal manager contracting, the economic determinants of the level of executive pay will perfectly describe the cross-sectional variation in the equilibrium level of executive compensation. In a properly specified regression model, the null hypothesis is that only variables that determine the firm's demand for a manager of a given quality should have explanatory power. Ownership and board variables should not be estimated significantly in such a model because they do not carry information beyond the firm characteristics that eventually determine optimal executive compensation. ${ }^{19}$ 
In contrast, if the ownership and/or board variables are estimated significantly in the compensation regression, one potential explanation is that the null hypothesis can be rejected and that there are unresolved agency problems. This evidence for managerial entrenchment could be interpreted as support for the managerial power hypothesis. However, an equally plausible interpretation is that there is an omitted variables problem, implying that the model for equilibrium compensation (omitting ownership and board variables) is misspecified. This problem occurs if the economic determinants cannot fully explain the equilibrium level of executive compensation and/or if the ownership and board variables proxy for the (unobserved) underlying economic determinants. ${ }^{20}$

As in Core et al. (1999), the dependent variable in our main regression is the logarithm of the total compensation (the sum of salary, bonus, and options and stock grants) of the "representative” executive in each firm. To model the equilibrium level of executive pay, we employ a set of economic determinants that reflect the range of managerial discretion across firms in our sample. Table 2 contains a description of all variables. We use sales to proxy for firm size and complexity (Size), and the firm's market-to-book ratio is a proxy for its investment opportunity set (Growth). ${ }^{21}$ In addition, we employ firm age (Age), the operating profit (return on assets, Profitability), the company stock return (Stock return), and firm risk (Sigma), measured as the standard deviation of the firm's stock return, and a dummy variable for inclusion in the Swiss Market Index (SMI), to model the costs and benefits of using different executive compensation contracts.

[Insert table 2 here]

The model in John and John (1993) predicts that firms with higher leverage (Leverage) will find it optimal to reduce the incentives provided by stock options in order to reduce the expected agency costs of debt (e.g., risk shifting). Jensen (1986) and Easterbrook (1986) argue that firms with higher leverage and higher dividend yields (Dividend yield) are more closely monitored, and stronger market monitoring may be consistent with lower equilibrium wages. In contrast, Yermack (1995) argues that firms that omit paying dividends face liquidity constraints and substitute stock options for straight salary in the compensation packages. Finally, to control for differences in managerial discretion and the demand for managerial talent across industries (e.g., Demsetz und Lehn, 1985), we use seven industry dummy variables according to the classification of Swiss Exchange and estimate an industry fixed effects model. 
To disentangle the optimal contracting approach from the managerial power hypothesis, we include a set of ownership and board variables in the compensation regression, along with the hypothesized economic determinants. The ownership variables are: (i) the percentage of voting rights exercised by the largest shareholder (Lshare), (ii) the percentage of equity owned by officers and directors (Stocksod), and (iii) the percentage of cumulated voting rights exercised by large outside investors with more than 5 percent of the voting rights (Blockout). In line with the view that the presence of a large outside shareholder encourages closer monitoring by virtue of a takeover threat (e.g., Shleifer and Vishny, 1986), the model in Cyert et al. (2002) predicts a negative relationship between equity compensation and ownership of the largest shareholder. Based on Jensen and Meckling's (1984) seminal analysis, Mehran (1995), Core et al. (1999), and Cyert et al. (2002) document that incentives provided by stock options decrease if the executives’ personal stock ownership increases. Hartzell and Starks (2003) provide evidence that the presence of institutional investors increases the pay-for-performance sensitivity and decreases the level of compensation. ${ }^{22}$ The variable Blockout captures mainly ownership of large pension funds and mutual funds, and we use it to test whether institutional investors limit manager pay.

The variables related to the board of directors are: (i) board size (Bsize), (ii) a dummy variable indicating whether the CEO is also the chairman of the board (Ceoc), and (iii) outside membership on the board, measured as the percentage of board seats held by non-officers without any relationship to the founding family (Outsider). Jensen (1993) and Yermack (1996) suggest that the size of the board of directors is associated with less effective board monitoring because larger boards are less effective due to director free-riding and more susceptible to the influence of the CEO. ${ }^{23}$ Yermack (1996) also provides evidence for more pronounced agency problems under CEO duality. The model in Hermalin and Weisbach (1998) predicts that CEO turnover is more sensitive to performance when the board is more independent. Shivdasani and Yermack (1999) and Beiner et al. (2006) document that the concentration of power associated with CEO duality leads to the election of less independent board members. Consistent with these findings, Core at al. (1999) report that the level of executive pay is positively related to board size and CEO duality, and negatively related to the number of outside directors.

Bebchuk and Fried (2003) suggest that the managerial power hypothesis not only refers to the level of total executive compensation but also the pay-for-performance sensitivity. Therefore, as in Yermack (1995) and Hartzell and Starks (2003), we also estimate our regression model 
using a measure for the steepness of the relationship between executive pay and shareholder wealth as the dependent variable. Following Yermack's (1995) technique, we compute the option-grant sensitivity by calculating the delta of every option grant, $\partial C / \partial P$ (where $C$ is the value of the call option and $P$ is the price of the stock), using the Black and Scholes (1973) model. We multiply the delta of the options by the number of options granted and divide by the total number of shares outstanding at the beginning of 2002. We then multiply by 1'000 to get the Swiss franc change in managerial wealth per CHF 1'000 change in shareholder wealth. The average option grant-sensitivity in our sample is CHF 0.44 per CHF 1'000, with a median of CHF 0.05 and a standard deviation of CHF 1.01. These figures for Switzerland are smaller than Yermack’s (1995) mean and median of \$0.59 and \$0.07 per \$1’000 for US data, respectively. Because options make up only a small portion of total managerial compensation in our sample, we use a measure for the total (weighted) pay-for-performance sensitivity, which is computed using the relative weights of cash, stock, and options in each payment package. With this alternative measure, the steepness of the relationship between total compensation and shareholder wealth decreases to only CHF 0.14 per CHF 1'000 change in shareholder wealth, on average, with a median of CHF 0.02 and a standard deviation of CHF $0.37 .^{24}$

Hall and Murphy (2002) argue that the certainty-equivalent approach adjusts for the riskiness of a manager's pay and the degree of personal under-diversification. To test this hypothesis, we rerun the level of pay regressions using the economic determinant variables and an additional dummy variable, which is one if the firm's executives belong to the top 10 percent in terms of total pay (Top 10p), and zero otherwise. We identify the top 10 percent earners on the basis of the market values of their compensation packages. By construction, the coefficient on the dummy variable Top $10 p$ must be positive in regressions where the market value of a compensation package is used as the independent variable. The more interesting question is whether the estimated coefficient decreases in magnitude when the risk-adjusted value of the firm's compensation package is used as the dependent variable. ${ }^{25}$ If the high compensation packages received by the top earners are attributable to the riskiness of their pay and/or less than optimal personal diversification, then in the presence of the determinant variables for the equilibrium level of manager pay, the null hypothesis is that the dummy variable Top $10 p$ is no longer estimated significantly when risk-adjusted values of executive pay are used. To test the (less stringent) hypothesis that the estimated coefficients on the dummy variable Top10p are identical irrespective of whether market values or risk adjusted values of total compensation are used as dependent variable, we estimate a system of simultaneous equations using Zell- 
ner's (1963) seemingly unrelated regression (SUR) technique. The explanatory variables are the same in all equations, i.e., the economic determinant variables in addition to Top $10 p$, and therefore the estimated coefficients using SUR are identical to OLS. However, because the error terms are correlated across equations and SUR estimates the full variance-covariance matrix of the coefficients, it is possible to perform joint coefficient tests.

\subsection{Regression results}

Table 3 summarizes our regression results. Column I contains the results from industry fixed effects regressions using the economic determinant variables together with the ownership and board variables. Consistent with the predictions of Gabaix and Landier's (2006) model, total executive pay increases with firm size (Size), presumably because size is a proxy for complexity and the demand for better qualified managers. ${ }^{26}$ As in Smith and Watts (1992), our results suggest that firms with more growth opportunities (Growth) require more skilled managers and use more incentive plans, and they will possibly pay higher equilibrium wages. Agency theory predicts that the level of manager pay will be an increasing function of firm performance (e.g., Jensen and Murphy, 1990), explaining the significantly positive coefficient on the annual stock market return (Stock return). Finally, older firms (Age) tend to pay lower wages. While all other variables used to model equilibrium wages are estimated insignificantly, overall these results for our small sample of Swiss firms are consistent with previous empirical evidence (e.g., Core et al., 1999). ${ }^{27}$

Contradicting John and John's (1993) notion that firms with higher leverage will reduce the incentives provided by stock options to reduce the expected agency costs of debt, Leverage is estimated significantly positive in column I. Lewellen et al. (1987) also report a positive relationship, but Yermack (1995) cannot detect a significant association between financial leverage and incentives from stock options. The coefficient on Dividend yield is estimated insignificantly. This result could be explained by two opposing effects. On the one hand, firms that omit paying dividends face liquidity constraints and substitute stock options for straight salary in the compensation packages (e.g., Yermack, 1995), but on the other hand firms with high payout ratios are more closely monitored by the market, inducing reduced managerial discretion and arguably lower equilibrium wages (e.g., Easterbrook, 1986).

[Insert table 3 here] 
Looking at the board and ownership variables, only the coefficient of Bsize is estimated significantly positive. This result is consistent with Jensen's (1993) ad-hoc notion that larger boards induce reduced monitoring due to director free-riding as well as the empirical results in Core et al. (1999), who document that CEO compensation is higher when the board is larger. Assuming that the level of equilibrium executive compensation is correctly specified, this result could be interpreted as providing support for Bebchuk and Friend's (2003) managerial power hypothesis, i.e., that managerial entrenchment leads to higher executive pay. However, the estimated coefficients on all other ownership and board variables do not provide further insights. The insignificant coefficient on Lshare could again be explained by two opposing effects. On the one hand, the presence of a large shareholder leads to better monitoring and lower executive compensation (e.g., Cyert, 2002), but on the other hand a controlling shareholder can appropriate private benefits not shared by other shareholders of the firm (e.g., Barclay and Holderness, 1989). The firm's management is usually hired and fired by the controlling shareholder, and often the two parties coincide, which arguably leads to higher executive compensation. The insignificant coefficient on managerial ownership (Stocksod) agrees with the results in Lewellen et al. (1987) and Yermack (1995), but it does not support the inverse relationship documented by Mehran (1995), Core et al. (1999), and Cyert et al. (2002). Although the estimated coefficient carries the expected sign, our results cannot confirm Hartzell and Starks’ (2003) finding that institutional ownership (Blockout) is significantly negatively related to the level of compensation due to closer monitoring and greater scrutiny of managers. A positive coefficient on Ceoc suggests that CEO duality leads to managerial entrenchment and higher executive compensation, and the negative coefficient on Outsider indicates that outside directors presumably make boards more independent and limit manager pay. However, in contrast to Core et al. (1999), both relationships are estimated insignificantly. ${ }^{28}$

Columns II shows the results when the total pay-for-performance (PFP) sensitivity is used as the dependent variable. To the extent that our economic determinant variables proxy for the expected agency costs of the firm, observing that these variables are generally estimated insignificantly could indicate that firms do not follow optimal compensation practices. Jensen and Murphy (1990) and Yermack (1995) also document that the performance incentives of stock options have only a weak association with explanatory variables related to agency cost reduction. Similar to Bizjak et al. (1993) and Yermack (1995), we report a negative (albeit insignificant) relationship between growth opportunities (Growth) and the total pay for performance sensitivity. This result is surprising because growth opportunities are generally as- 
sumed to proxy for higher information asymmetries and more pronounced agency costs, presumably requiring a higher pay-for-performance sensitivity (e.g., Hartzell and Starks, 2003). The significantly negative coefficient on Outsider is also hard to explain. Theory suggests that the presence of outside directors will lead to more efficient compensation contracts with higher pay-for-performance sensitivity. Moreover, we cannot replicate Hartzell and Starks' (2003) finding that the firm's pay-for-performance sensitivity is significantly positively related to the concentration of institutional ownership. The coefficient on Blockout is estimated insignificantly. Overall, it may nevertheless be premature to blame Swiss firms' that they do not follow optimal compensation practices, which could be one explanation for our weak results when the pay-for-performance sensitivity is used as the dependent variable. Although the set of explanatory variables follows previous research, it is equally possible that our regression model is misspecified. The adjusted R-square drops from $54 \%$ in the level of pay regression in column I to only 9\% in column II, and the only governance variable that is estimated significantly, Outsider, could be correlated with the (unobserved) underlying economic determinants.

Finally, columns III-V show the results of our system of equations that omits the ownership and board variables, but includes the dummy variable Top $10 p$, which is one if the firm's executives belong to the top $10 \%$ in terms of total pay, and zero otherwise. Using the market value and the risk-adjusted values of executive compensation (with $\rho=3$ and $\rho=10$ ) as the dependent variables, we estimate the resulting system of equations using SUR. A first observation is that Dividend yield is now estimated significantly negative, supporting Easterbrook's (1986) notion that firms with higher payout ratios are more closely monitored. Our main hypothesis, however, is that if we adjust for the riskiness of equity-based compensation packages and poor diversification, the coefficient on Top $10 p$ decreases with increasing relative risk aversion (or even becomes insignificant). As predicted, the estimated coefficient on Top $10 p$ decreases (from 1.17 using market values to 1.07 in the certainty-equivalent setup with $\rho=10$ ), but it nevertheless remains statistically significant even in the presence of our control variables. The coefficient on Top $10 p$ in column III indicates that the average pay of executives in the $10 \%$ highest paying Swiss firms is $222 \%$ higher than in other firms, on average. ${ }^{29}$ Looking at the estimated coefficients in columns IV and V, the average total pay of the top earning executives is still $206 \%$ and $192 \%$ higher than that of the other firms in the sample assuming $\rho=3$ and $\rho=10$, respectively. A Wald coefficient test (reported at the bottom of the table) cannot reject the null hypothesis that all three coefficients are identical across 
equations ( $p$-value $=0.135$ ). We control for the business risk of the firm by including the standard deviation of stock returns over the prior five years, but the corresponding coefficient is again estimated insignificantly. Overall, we reject the null hypothesis that cross-sectional differences in the amount of executive pay vanish when risk-adjusted values are used as dependent variables. The high compensation level of the top 10\% earners seems not solely justified by the risk inherent in their compensation package and/or their firm's underlying business.

There is one final observation. Yermack (1995) claims that the range of managerial discretion is reduced for firms in regulated industries (e.g., utility and banking industries), and therefore these firms should contract lower compensation packages and less incentives from stock options. The SUR system in column III-V includes industry dummy variables, and our results (not tabulated here) indicate that only the dummy variable for the financial services sector is estimated significantly positive. This contradicts with the general perception about regulated industries (e.g., Demsetz and Lehn, 1985; Adams and Mehran, 2003), but it can easily be explained by the two outlier financial institutions UBS and Swiss Re in our sample.

\section{Conclusions}

This paper focuses on two related implications of equity-linked compensation plans. First, it is well acknowledged among both academics and practitioners that Black-Scholes values overstate the true value of executive stock options. When opportunity costs are taken into account, stock options are an expensive way to convey pay. The Black-Scholes values provide an estimate of the company's cost of granting an option, but they do not estimate the value of a non-tradable option to risk averse and undiversified executives. We take a Swiss perspective and employ the certainty-equivalence approach used by Hall and Murphy (2002) to estimate this value cost-wedge. We refine their setup to account for the prevailing disclosure requirements in Switzerland. Even for moderate relative risk aversion coefficients of 2 and 3, we estimate discounts of $39 \%$ and $56 \%$ relative to Black-Scholes values, respectively. In absolute terms, these losses translate into CHF 88 million and CHF 126 million. If we include all outstanding option packages as of December 31, 2002, we estimate discounts of $47 \%$ and $62 \%$ (or CHF 290 million and CHF 377 million). Clearly, these deadweight losses appear small compared to the aggregate stock market capitalization of our sample firms, but with the increasing use of executive stock options in Swiss compensation packages the losses will exac- 
erbate. At some point, the deadweight losses will turn out substantial and the efficiency of option grants becomes a major issue.

Second, we take a closer look at the relationship between the level of total executive compensation, the pay-for-performance sensitivity, and several aspects of the firm's corporate governance structure. The equilibrium level of executive compensation is explained by economic determinant variables, e.g., firm size, growth opportunities, and prior stock returns. Among the board and ownership variables we use, only board size is estimated significantly. Specifically, firms with a larger board of directors pay higher total compensation, indicating potentially unresolved agency problems due to director free-riding and inefficient decision making processes within the board. In contrast, the pay-for-performance sensitivity is unrelated to both the economic determinant variables for the equilibrium level of pay and to our board and ownership variables. Although model specification problems may be an issue, this result could be interpreted as indication that at the moment Swiss firms do not utilize executive compensation efficiently. The final question we address is whether the cross-sectional differences in the level of executive pay vanish when risk-adjusted values are employed. We document that the top $10 \%$ earners among Swiss executives receive a significantly higher compensation even when we control for the risk inherent in equity-based compensation, the manager's under-diversification, and the firm's business risk.

Taken together, our data do not allow us to draw final conclusions. On the one hand, we find some evidence that firms with weaker corporate governance structures pay higher wages, potentially indicating deviations from the arm's length approach. On the other hand, our results are not compelling enough to provide support for the managerial power approach. We therefore conclude that the horse-race is still undecided. Alternatively, financial economists' theories of optimal compensation contracts could be incomplete or incorrect, implying that our regression models are misspecified. Another possibility is that the data and methodology used in this study have inadequate power for measuring managerial incentives. With more detailed data and the use of panel methodology, future research will be able to provide further insight. 


\section{References:}

Adams, R., and H. Mehran, 2003, Is corporate governance different for bank holding companies? FRBNY Economic Policy Review, 123-142.

Agrawal, A., and C.R. Knoeber, 1996, Firm performance and mechanisms to control agency problems between managers and shareholders, Journal of Financial and Quantitative Analysis 31, 377-397.

Baker, G., M. Jensen, and K. Murphy, 1988, Compensation and incentives: Practice vs. theory, Journal of Finance 43, 593-616.

Banker, D., and S. Datar, 1989, Sensitivity, precision, and linear aggregation of signals for performance evaluation, Journal of Accounting Research 27, 21-39.

Barclay, M.J., and C.G. Holderness, 1989, Private benefits of control of public corporations, Journal of Financial Economics 25, 371-395.

Bebchuk, L., and J. Fried, 2003, Executive compensation as an agency problem, Journal of Economic Perspectives 17, 71-92.

Bebchuk, L., and J. Fried, 2004, Pay without performance: The unfulfilled promise of executive compensation, Cambridge: Harvard University Press.

Bebchuk, L., J. Fried, and D. Walker, 2002, Managerial power and rent extraction in the design of executive stock options, University of Chicago Law Review 69, 751-846.

Beiner, S., W. Drobetz, F. Schmid, and H. Zimmermann, 2004, Is board size an independent corporate governance mechanism?, Kyklos 57, 327-356.

Beiner, S., W. Drobetz, M.M. Schmid, and H. Zimmermann, 2006, An integrated framework of corporate governance and firm valuation, European Financial Management 12, 249-283.

Bettis, J.C., J.M. Bizjak, and M.L. Lemmon, 2001, Managerial ownership, incentive contracting, and the use of zero-cost collars and equity swaps by corporate insiders, Journal of Financial and Quantitative Analysis 36, 345-371.

Bizjak, J., J. Brickley, and J. Coles, 1993, Stock-based incentive compensation and investment behavior, Journal of Accounting and Economics 16, 349-72.

Black, F., and M. Scholes, 1973, The pricing of options and corporate liabilities, Journal of Political Economy 81, 637-659.

Börsch-Supan, A., and J. Köke, 2002, An applied econometricians' view of empirical corporate governance studies, German Economic Review 3, 295-326.

Bound, J., D. Jaeger, and R. Baker, 1995, Problems with instrumental variables estimation when the correlations between the instruments and the endogenous explanatory variables is weak, Journal of the American Statistical Association 90, 443-450.

Burkart, M. D. Gromb, and F. Panuzi, 1997, Large shareholders, monitoring, and the value of the firm, Quarterly Journal of Economics 112, 693-728.

Carpenter, J.N., 2000, Does option compensation increase managerial risk appetite?, Journal of Finance 55, 2311-2331.

Chidambaran, N., and K. John, 1999, Relationship investing, managerial compensation, and corporate governance, Working Paper, Tulane University and New York University.

Cohen, R.B., Hall, B.J., and L.M. Viceira, 2000, Do executive stock options encourage risktaking?, Working Paper, Harvard University.

Core, J.E., R.W. Holthausen, and D.F. Larcker, 1999, Corporate governance, chief executive officer compensation, and firm performance, Journal of Financial Economics 51, 371-406. 
Cyert, R., S.H., Kang, and P. Kumar, 2002, Corporate governance, takeovers, and top management compensation: Theory and evidence, Management Science 41, 200-208.

Davidson, R., and J. MacKinnon, 1993, Estimation and inference in econometrics, Oxford University Press.

Demsetz, H., and K. Lehn, 1985, The structure of corporate ownership: Causes and consequences, Journal of Political Economy 93, 1155-1177.

Drobetz, W., 2001, Wie hoch ist die Marktrisikoprämie in der Schweiz?, Working Paper, University of Basel.

Drobetz, W., G. Wanzenried, P. Kugler, and H, Zimmermann, 2006, Investor heterogeneity and asset allocation decisions: Evidence from Switzerland, Working Paper, University of Basel.

Easterbrook, F., 1986, Two agency-cost explanations of dividends, American Economic Review 74, 650-659.

Frey, B.S., and M. Osterloh, 2000, Pay for performance - Immer empfehlenswert?, Zeitschrift für Führung und Organisation 69, 64-69.

Gabaix, X., and A. Landier, 2006, Why has CEO pay increased so much?, Working Paper, Massachusetts Institute of Technology.

Gillan, S., and L. Starks, 2000, Corporate governance proposals and shareholder activism: The role of institutional investors, Journal of Financial Economics 57, 275-305.

Hall, B.J., and J.B. Liebman, 1998, Are CEOs really paid like bureaucrats?, Quarterly Journal of Economics 113, 653-691.

Hall, B.J., and K.J. Murphy, 2002, Stock options for undiversified executives, Journal of Accounting and Economics 33, 3-42.

Harris, M., and A. Raviv, 1979, Optimal incentive contracts with imperfect information, Journal of Economic Theory 20, 231-259.

Hartzell, J., and L. Starks, 2003, Institutional investors and executive compensation, Journal of Finance 58, 2351-2376.

Hausman, J.A., 1978, Specification tests in econometrics, Econometrica 46, 1251-1271.

Hellwig, M., 1997, Unternehmensfinanzierung, Unternehmenskontrolle und Ressourcenallokation: Was leistet das Finanzsystem?, in: Gahlen, B., H. Hesse und H. Ramser (eds.), Finanzmärkte, Mohr (Paul Siebeck), 211-243.

Hermalin, B., and S. Weisbach, 1998, Endogenously chosen boards of directors and their monitoring of the CEO, American Economic Review 88, 96-118

Himmerlberg, C.P., R.G. Hubbard, and D. Palia, 1999, Understanding the determinants of managerial ownership and the link between ownership and performance, Journal of Financial Economics 53, 353-384.

Holmström, B., 1979, Moral hazard and observability, Bell Journal of Economics 10, 74-91.

Holmstom, B. and J. Tirole, 1993, Market liquidity and performance monitoring, Journal of Political Economy 101, 678-709.

Jensen, M., 1986, Agency costs of free cash flows, corporate finance, and takeovers. American Economic Review 76, 323-339.

Jensen, M., 1993, The modern industrial revolution, exit, and the failure of internal control systems, Journal of Finance 48, 831-880.

Jensen, M., and W. Meckling, 1976, Theory of the firm: Managerial behavior, agency costs, and ownership structure, Journal of Financial Economics 3, 305-360. 
Jensen, M., and K.J. Murphy, 1990, Performance pay and top management incentives, Journal of Political Economy 98, 225-264.

John, T., and K. John, 1993, Top-management compensation and capital structure, Journal of Finance 48, 949-74.

Lambert, R.A., Larcker, D.F., and R.E. Verrechia, 1991, Portfolio considerations in valuing executive compensation, Journal of Accounting Research 29, 129-149.

Leland, H., and D. Pyle, 1977, Information asymmetries, financial structure, and financial intermediation, Journal of Finance 32, 371-387.

Lewellen, W., C. Loderer, and K. Martin, 1987, Executive compensation and executive incentive problems: An empirical analysis, Journal of Accounting and Economics 9, 287-310.

Loderer, C. and Zgraggen, P., 1999, When shareholders choose not to maximize value - the Union Bank of Switzerland's 1994 proxy fight, Journal of Applied Corporate Finance 12, 91102.

Manne, H., 1965, Mergers and the market for corporate control, Journal of Political Economy 73, 110-120.

Mehran, H., 1995, Executive compensation structure, ownership, and firm performance, Journal of Financial Economics 38, 163-184.

Meulbroek, L., 2001, The efficiency of equity-linked compensation: Understanding the full cost of awarding executive stock options, Financial Management 30, 5-44.

Murphy, K.J., 1999, Executive compensation, in: Ashenfelter O. and Card D. (eds.): Handbook of Labor Economics (North-Holland, Amsterdam).

Rüdisühli, H., and A. Orler, 2005, Mitarbeiterbeteiligungen - endlich eine gesetzliche Regelung, Der Schweizer Treuhänder 1-2/05, 74-84.

Shleifer, A., and R.W. Vishny, 1986, Large shareholders and corporate control, Journal of Political Economy 94, 461-488.

Shivdasani, A., and D. Yermack, 1999, CEO involvement in the selection of new board members: An empirical analysis, Journal of Finance 54, 1829-1854.

Silber, W., 1991, Discount on restricted stock: The impact of illiquidity on stock prices, $F i$ nancial Analysts Journal 47, 60-64.

Smith, M., 1996, Shareholder activism by institutional investors: Evidence from CalPERS, Journal of Finance 51, 227-252

Smith, C.W., and R.L. Watts, 1992, The investment opportunity set and corporate financing, dividend, and compensation policies, Journal of Financial Economics 32, 263-292.

Yermack, D., 1995, Do corporations award CEO stock options effectively?, Journal of Financial Economics 39, 237-269.

Yermack, D., 1996, Higher market valuation of companies with a small board of directors, Journal of Financial Economics 40, 185-211.

Zellner, A., 1963, Estimators for seemingly unrelated regression equations: Some exact finite sample results, Journal of the American Statistical Association 58, 977-992. 
Table 1: Compensation structure in 2002

\begin{tabular}{lrrrr}
\hline \hline & Cash & Stock & Options & Total \\
\hline Minimum & CHF 39,706 & 0 & 0 & 86,386 \\
Mean & 511,392 & 74,152 & 168,431 & 753,975 \\
Median & 351,500 & 0 & 20,254 & 410,713 \\
Maximum & $4,929,632$ & $2,451,385$ & $2,498,122$ & $8,932,520$ \\
\hline \hline
\end{tabular}

The table displays descriptive statistics of the value and the composition of the compensation package paid to the "representative" Swiss executive during the reporting year 2002. The sample contains 78 Swiss firms with detailed information about compensation structures for members of the board of directors and executive members. Executive options are valued with the Black-Scholes (1973) methodology, using stock prices as of year-end 2002. The volatility of a firms' stock return is estimated using monthly data over the 1999-2002 period. All numbers are in Swiss francs (CHF). 
Table 2: Description of variables

\begin{tabular}{|c|c|c|c|c|}
\hline \multicolumn{5}{|c|}{ Panel A: Summary of variables } \\
\hline Size & \multicolumn{4}{|c|}{ Natural logarithm of total sales in 2002} \\
\hline Growth & \multicolumn{4}{|c|}{ Market-to-book ratio as of year-end 2002} \\
\hline Age & \multicolumn{4}{|c|}{ Natural logarithm of years since inception as a public corporation } \\
\hline Profitability & \multicolumn{4}{|c|}{ 3-year average ratio of operating income to total assets (2000-2002, return on assets) } \\
\hline Stock return & \multicolumn{4}{|c|}{ Average annual stock return (2001-2002) } \\
\hline Sigma & \multicolumn{4}{|c|}{ Standard deviation of stock returns estimated from 60 monthly stock returns } \\
\hline$S M I$ & \multicolumn{4}{|c|}{1 , if the company belongs to the Swiss Market Index; 0 otherwise } \\
\hline Dividend yield & \multicolumn{4}{|c|}{ Annual dividend yield as of year-end 2002} \\
\hline Leverage & \multicolumn{4}{|c|}{ Leverage, measured as the ratio of total (non-equity) liabilities to total assets } \\
\hline Lshare & \multicolumn{4}{|c|}{ Percentage of voting rights exercised by the largest shareholder } \\
\hline Stocksod & \multicolumn{4}{|c|}{$\begin{array}{l}\text { Percentage of equity owned by officers and directors (if the firm has different share } \\
\text { categories with different voting rights attached, nominal values of different share } \\
\text { categories are used for weighting) }\end{array}$} \\
\hline Blockout & \multicolumn{4}{|c|}{$\begin{array}{l}\text { Percentage of cumulated voting rights exercised by large outside investors (non- } \\
\text { group listed companies, mutual funds, and pension funds) with }>5 \% \text { of voting rights }\end{array}$} \\
\hline Bsize & \multicolumn{4}{|c|}{ Number of directors on the board of the company } \\
\hline $\mathrm{Ceoc}$ & \multicolumn{4}{|c|}{ 1, if the CEO is also the president of the board; 0 otherwise } \\
\hline Outsider & \multicolumn{4}{|c|}{$\begin{array}{l}\text { Outsider membership on the board, measured by the percentage of board seats held } \\
\text { by non-officers without relationship to the founding family (if any) }\end{array}$} \\
\hline \multicolumn{5}{|c|}{ Panel B: Descriptive statistics } \\
\hline & Mean & Median & Standard deviation & Min./Max. \\
\hline Size & 13.729 & 13.738 & 2.439 & $0.000 / 18.310$ \\
\hline Growth & 1.800 & 1.455 & 1.317 & $0.450 / 8.440$ \\
\hline Age & 3.462 & 3.450 & 1.255 & $1.386 / 6.277$ \\
\hline Profitability & 0.042 & 0.056 & 0.095 & $-0.500 / 0.250$ \\
\hline Stock return & -0.279 & -0.271 & 0.256 & $-0.857 / 0.887$ \\
\hline Sigma & 0.420 & 0.369 & 0.193 & $0.088 / 0.897$ \\
\hline$S M I$ & 0.244 & 0.000 & 0.432 & $0.000 / 1.000$ \\
\hline Dividend yield & 0.017 & 0.012 & 0.019 & $0.000 / 0.072$ \\
\hline Leverage & 0.238 & 0.225 & 0.167 & $0.000 / 0.666$ \\
\hline Lshare & 0.265 & 0.209 & 0.231 & $0.000 / 0.862$ \\
\hline Stocksod & 0.158 & 0.016 & 0.233 & $0.000 / 0.858$ \\
\hline Blockout & 0.112 & 0.064 & 0.161 & $0.000 / 0.862$ \\
\hline Bsize & 6.987 & 6.000 & 2.436 & $3.000 / 16.000$ \\
\hline Ceoc & 0.192 & 0.000 & 0.397 & $0.000 / 1.000$ \\
\hline Outsider & 0.872 & 0.857 & 0.125 & $0.500 / 1.000$ \\
\hline
\end{tabular}


Table 3: Regression results

Dependent variable:

\begin{tabular}{|c|c|c|c|c|c|}
\hline $\begin{array}{l}\text { Independent } \\
\text { variables: }\end{array}$ & $\begin{array}{l}\text { Market values } \\
\text { (I) }\end{array}$ & $\begin{array}{l}\text { PFP-sensitivity } \\
\text { (II) }\end{array}$ & $\begin{array}{l}\text { Market values } \\
\text { (III) }\end{array}$ & $\begin{array}{l}\rho=3 \\
(\mathrm{IV})\end{array}$ & $\begin{array}{c}\rho=10 \\
(\mathrm{~V})\end{array}$ \\
\hline Size & $\begin{array}{l}0.153^{* * *} \\
(2.78)\end{array}$ & $\begin{array}{l}0.025 \\
(1.08)\end{array}$ & $\begin{array}{l}0.117^{* * *} \\
(3.99)\end{array}$ & $\begin{array}{l}0.132^{* * *} \\
(3.87)\end{array}$ & $\begin{array}{l}0.126^{* * * *} \\
(3.85)\end{array}$ \\
\hline Growth & $\begin{array}{l}0.139 * * * \\
(2.40)\end{array}$ & $\begin{array}{l}-0.051 \\
(-1.11)\end{array}$ & $\begin{array}{l}0.141^{* * *} \\
(2.58)\end{array}$ & $\begin{array}{c}0.088 \\
(1.38)\end{array}$ & $\begin{array}{l}0.103^{*} \\
(1.70)\end{array}$ \\
\hline Age & $\begin{array}{l}-0.134^{*} \\
(-1.92)\end{array}$ & $\begin{array}{r}0.001 \\
(0.02)\end{array}$ & $\begin{array}{l}-0.063 \\
(-1.20)\end{array}$ & $\begin{array}{r}-0.057 \\
(-0.93)\end{array}$ & $\begin{array}{c}-0.054 \\
(-0.91)\end{array}$ \\
\hline Profitability & $\begin{array}{r}0.472 \\
(0.66)\end{array}$ & $\begin{array}{l}-0.087 \\
(-0.19)\end{array}$ & $\begin{array}{c}0.493 \\
(0.75)\end{array}$ & $\begin{array}{c}0.736 \\
(0.96)\end{array}$ & $\begin{array}{r}0.742 \\
(1.01)\end{array}$ \\
\hline Stock return & $\begin{array}{l}1.082^{* * * *} \\
(3.31)\end{array}$ & $\begin{array}{r}0.159 \\
(1.09)\end{array}$ & $\begin{array}{l}0.774^{* * *} \\
(2.93)\end{array}$ & $\begin{array}{l}0.579 * \\
(1.88)\end{array}$ & $\begin{array}{r}0.487 \\
(1.64)\end{array}$ \\
\hline Sigma & $\begin{array}{r}0.589 \\
(1.09)\end{array}$ & $\begin{array}{r}0.201 \\
(0.84)\end{array}$ & $\begin{array}{c}0.332 \\
(0.84)\end{array}$ & $\begin{array}{l}-0.111 \\
(-0.24)\end{array}$ & $\begin{array}{c}-0.140 \\
(-0.31)\end{array}$ \\
\hline$S M I$ & $\begin{array}{r}0.097 \\
(0.44)\end{array}$ & $\begin{array}{c}-0.099 \\
(-0.78)\end{array}$ & $\begin{array}{c}0.032 \\
(0.18)\end{array}$ & $\begin{array}{l}-0.151 \\
(-0.73)\end{array}$ & $\begin{array}{c}-0.162 \\
(-0.81)\end{array}$ \\
\hline Dividend yield & $\begin{array}{l}-5.623 \\
(-1.22)\end{array}$ & $\begin{array}{l}1.447 \\
(0.49)\end{array}$ & $\begin{array}{l}-8.374 * * \\
(-2.35)\end{array}$ & $\begin{array}{l}-10.002 * * \\
(-2.41)\end{array}$ & $\begin{array}{l}-9.924 * * \\
(-2.48)\end{array}$ \\
\hline Leverage & $\begin{array}{l}0.967^{*} \\
(1.86)\end{array}$ & $\begin{array}{l}-0.114 \\
(-0.39)\end{array}$ & $\begin{array}{c}0.244 \\
(0.71)\end{array}$ & $\begin{array}{c}0.226 \\
(0.57)\end{array}$ & $\begin{array}{c}0.265 \\
(0.69)\end{array}$ \\
\hline Lshare & $\begin{array}{c}-0.312 \\
(-0.99)\end{array}$ & $\begin{array}{c}-0.185 \\
(-1.34)\end{array}$ & & & \\
\hline Stocksod & $\begin{array}{c}-0.147 \\
(-0.49)\end{array}$ & $\begin{array}{c}-0.003 \\
(-0.02)\end{array}$ & & & \\
\hline Blockout & $\begin{array}{c}-0.570 \\
(-1.21)\end{array}$ & $\begin{array}{c}-0.097 \\
(-0.43)\end{array}$ & & & \\
\hline Bsize & $\begin{array}{l}0.090^{* *} \\
(2.13)\end{array}$ & $\begin{array}{c}-0.001 \\
(-0.04)\end{array}$ & & & \\
\hline Ceоc & $\begin{array}{c}-0.020 \\
(-0.08)\end{array}$ & $\begin{array}{c}-0.082 \\
(-0.47)\end{array}$ & & & \\
\hline Outsider & $\begin{array}{c}0.042 \\
(0.06)\end{array}$ & $\begin{array}{l}-1.613^{*} \\
(-1.85)\end{array}$ & & & \\
\hline Top 10p & & & $\begin{array}{l}1.174^{* * *} \\
(5.53)\end{array}$ & $\begin{array}{l}1.117^{* * *} \\
(4.52)\end{array}$ & $\begin{array}{l}1.071^{* * * *} \\
(4.49)\end{array}$ \\
\hline $\mathrm{N}$ & 78 & 78 & 78 & 78 & 78 \\
\hline Adj. $\mathrm{R}^{2}$ & 0.538 & 0.088 & 0.720 & 0.612 & 0.613 \\
\hline$F$-test & 0.000 & 0.139 & 0.000 & 0.000 & 0.000 \\
\hline $\mathrm{H}_{0}$ : Coefficient & p10p in columns & III, IV, and V are & dentical & & 4.01 \\
\hline $\mathrm{H}_{0}$ : Coefficients & $10 p$ in columns & III and IV are ide & cal & & 0.29 \\
\hline $\mathrm{H}_{0}$ : Coefficient & $p 10 p$ in columns & III and V are iden & & & 1.00 \\
\hline $\mathrm{H}_{0}$ : Coefficient & $p 10 p$ in columns & IV and $\mathrm{V}$ are ider & & & $2.98 *$ \\
\hline
\end{tabular}


This table presents the regression results. Columns I and II contain the results from industry fixed effects regressions of the level of executive compensation and pay-for-performance sensitivity, respectively, on the economic determinants and different ownership and board variables. Columns III-V presents estimates from seemingly unrelated regressions (SUR) of the level of executive compensation on dummy variables whether the firm's executives belong to the top 10 percent in terms of total compensation using market values (column III), and risk adjusted values with $\rho=3$ (column IV) and $\rho=10$ (column $\mathrm{V}$ ) together with a common set of economic determinant variables for the equilibrium wage. The corresponding Wald test statistics involving the coefficients of Top $10 p$ across equations are reported at the bottom of the table. $F$-tests are performed in each equation for the simultaneous significance of all coefficients. The sample size $(N)$ is 78 in all equations. The numbers in parentheses are $t$-statistics based on robust standard errors using the White (1980) covariance matrix. */**/*** denotes statistical significance at the $10 \% / 5 \% / 1 \%$ level. 
Figure 1: Black-Scholes values and risk-adjusted values of option packages

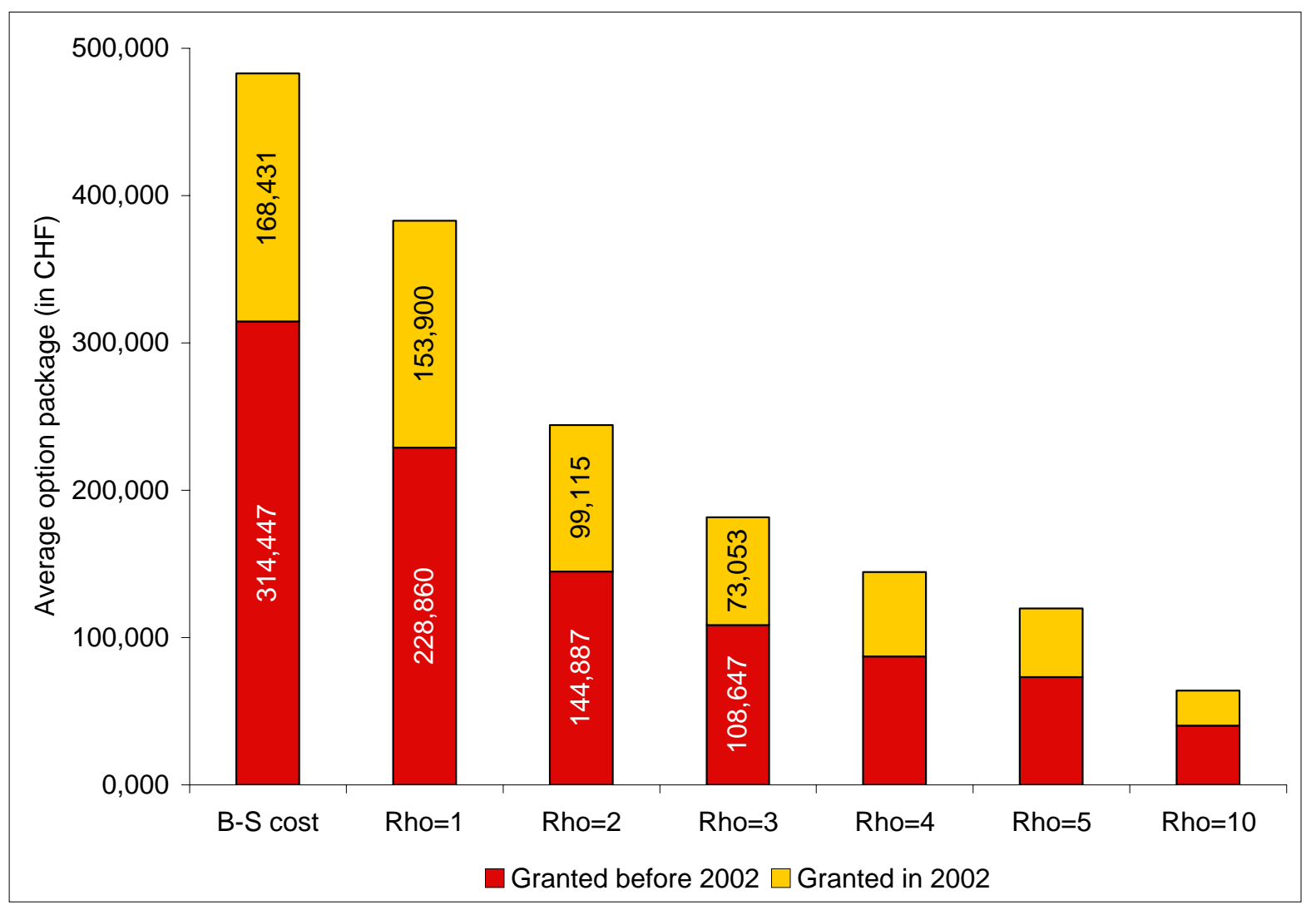

The figure shows the value of all stock options allotted in 2002 and before 2002 to the "representative" executive for a sample of 78 Swiss firms with detailed information about their compensation structures for members of the board of directors and executive members. The first bar shows the Black-Scholes (1973) (opportunity) cost incurred by the company, using 2002 year-end stock prices. The risk-adjusted values of the option packages for an executive in the remaining bars are estimated using the certainty equivalent approach proposed by Hall and Murphy (2002). The certainty equivalent is defined as the amount of riskless cash compensation the executive would exchange for the option. Assuming the executive has an initial wealth of the greater of CHF 5 million or four times yearly compensation, a differential equation is solved numerically, using power utility (with constant relative risk aversion, labelled as $\rho$, between 1 and 10) and a lognormal distribution of stock prices in $T$ with volatility $\sigma$ and expected value $\left(r_{f}+\beta\left(r_{m}-r_{f}\right)-\sigma^{2} / 2\right) \cdot T$, where $r_{f}=4.5 \%$ and $\left(r_{m}-r_{f}\right)=5.5 \%$. The volatility of a firms' stock return, $\sigma$, is estimated using monthly data over the 1999-2002 period. A firm's beta, $\beta$, is estimated from a market model regression over the same time window. 
Figure 2: Value of total compensation in 2002

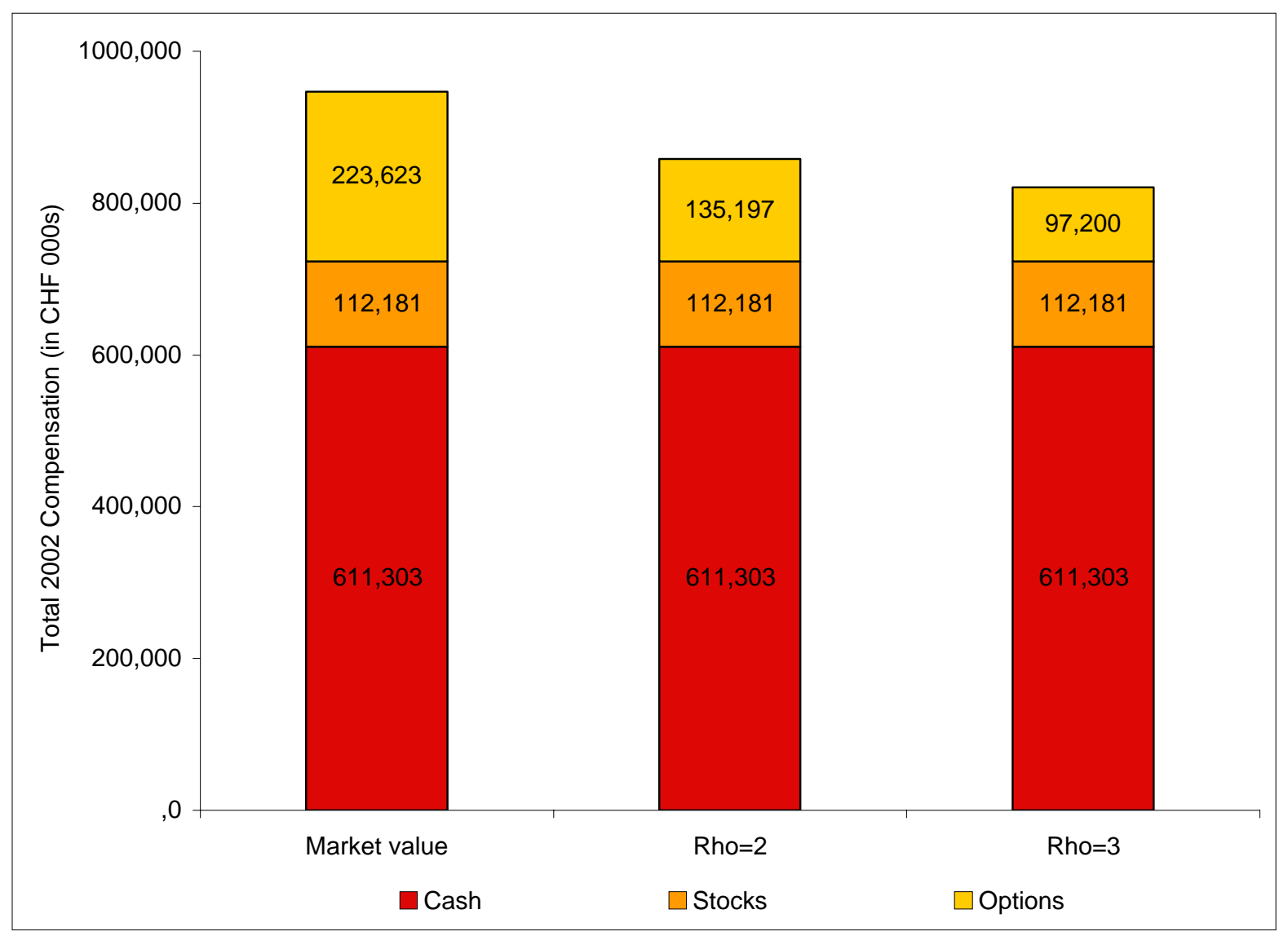

The figure shows the aggregate value of total executive compensation (including cash compensation, stock, and stock option allotments) paid in 2002 by a sample of 78 Swiss firms with detailed information about their compensation structures for members of the board of directors and executive members. The market value is computed with the Black-Scholes (1973) methodology to value stock options, using 2002 year-end stock prices. The risk-adjusted values of the compensation packages are estimated using the certainty equivalent approach proposed by Hall and Murphy (2002). The certainty equivalent is defined as the amount of riskless cash compensation the executive would exchange for the option. Assuming the executive has an initial wealth of the greater of CHF 5 million or four times yearly compensation, a differential equation is solved numerically, using power utility (with constant relative risk aversion $\rho=2$ or $\rho=3$ ) and a lognormal distribution of stock prices in $T$ with volatility $\sigma$ and expected value $\left(r_{f}+\beta\left(r_{m}-r_{f}\right)-\sigma^{2} / 2\right) \cdot T$, with $r_{f}=4.5 \%$ and $\left(r_{m}-r_{f}\right)=5.5 \%$. The volatility of a firms' stock return, $\sigma$, is estimated using monthly data over the 1999-2002 period. A firm's beta, $\beta$, is estimated from a market model regression over the same time window. 
Figure 3: Value of option packages outstanding in 2002

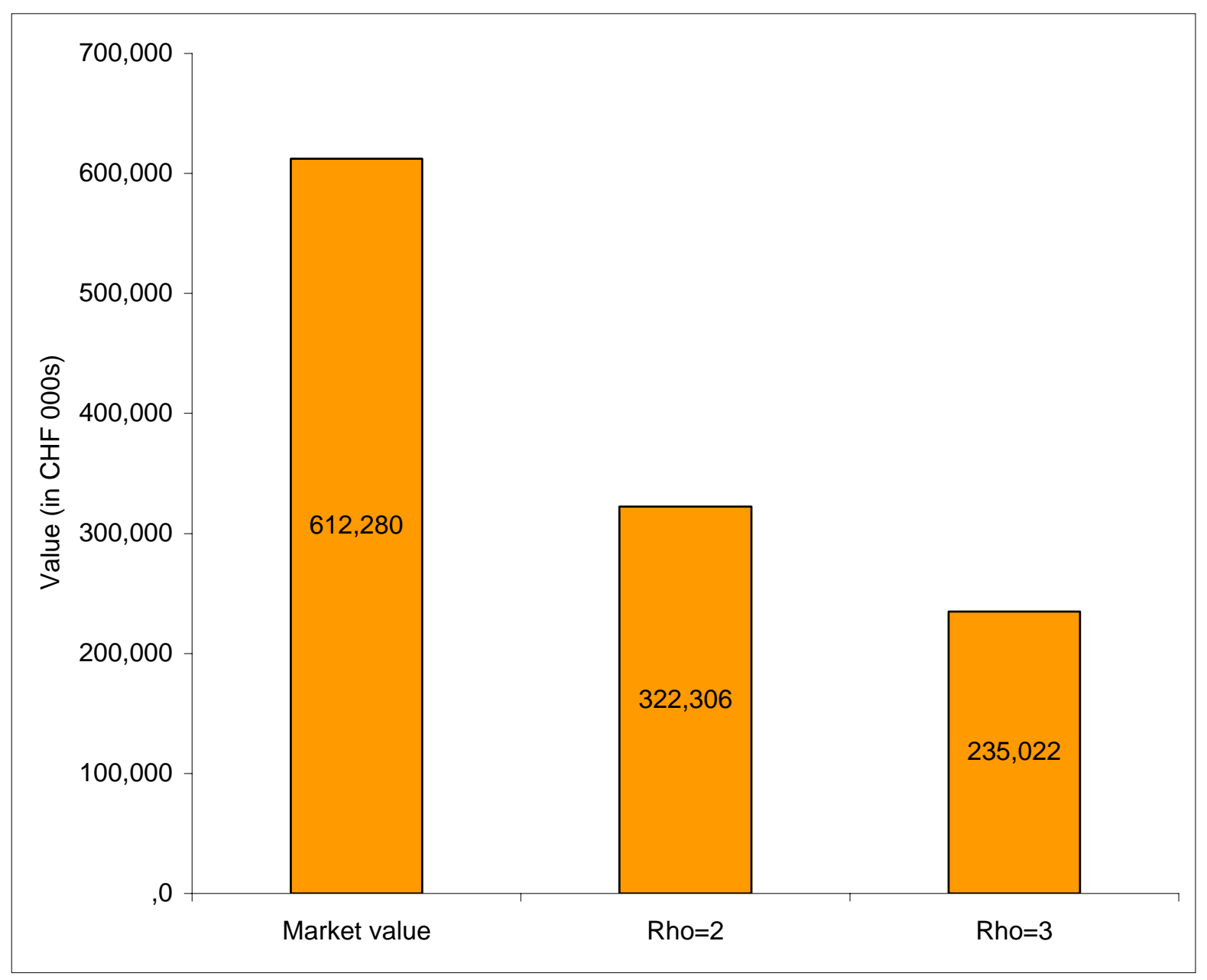

The figure shows the aggregate value of all executive options outstanding as of year-end 2002 for a sample of 78 Swiss firms with detailed information about their compensation structures for members of the board of directors and executive members. The market value of the options is computed with the Black-Scholes (1973) methodology, using 2002 year-end stock prices. The risk-adjusted values of the compensation packages are estimated using the certainty equivalent approach proposed by Hall and Murphy (2002). The certainty equivalent is defined as the amount of riskless cash compensation the executive would exchange for the option. Assuming the executive has an initial wealth of the greater of CHF 5 million or four times yearly compensation, a differential equation is solved numerically, using power utility (with constant relative risk aversion $\rho=1$ or $\rho=2$ ) and a lognormal distribution of stock prices in $T$ with volatility $\sigma$ and expected value $\left(r_{f}+\beta\left(r_{m}-r_{f}\right)-\sigma^{2} / 2\right) \cdot T$, where $r_{f}=$ 4.5\% and $\left(r_{m}-r_{f}\right)=5.5 \%$. The volatility of a firms' stock return, $\sigma$, is estimated using monthly data over the 1999-2002 period. A firm's beta, $\beta$, is estimated from a market model regression over the same time window. 
1 Bebchuk and Fried (2004) provide an up-to-date survey of the literature.

2 We analyze a sample of Swiss firms. Until now the Swiss accounting laws do not oblige firms to report stock options as an expense in their income statement. As far a tax issues are concerned, stock options are generally taxable upon exercise in Switzerland. For a detailed description of the current tax regulation in Switzerland see Rüdisühli and Orler (2005).

3 See Meulbroek (2001), p. 7.

4 Jensen and Murphy (1990) report that for every $\$ 1,000$ change in a company’s market value in a given year, the average CEO's total compensation for that year changed by three dollars. Hall and Liebman (1998) find that the pay-for-performance link had jumped almost tenfold since 1980; this change can be almost entirely attributed to the proliferation of stock options.

5 Carpenter (2000) and Cohen, Hall, and Viceira (2000) document that options do not strictly induce excessive managerial risk taking.

6 Restricted stock can be viewed as another example for a security with limited resale provisions, i.e., they can only be sold after a certain holding period. Silber (1991) documents that restricted stock is sold at an average price discount of roughly 34 percent. The discount is related to the size of the restricted offering relative to total shares outstanding as well as the credit-worthiness of the issuing company.

7 Bettis, Bizjak, and Lemmon (2001) document that managers use zero-cost collars and equity swaps to hedge the risk associated with their equity holdings. Managers even possess some timing abilities, i.e., they initiate hedging transactions immediately following large price run-ups and prior to poor earnings announcements.

8 In an earlier paper, Bebchuk et al. (2002) also suggest a „skimming view“, where the rise in executive compensation purely reflects managerial entrenchment. Managers attempt to change outrage costs and search for new means of camouflage. High-powered incentives are only an excuse used by the management to justify higher rent extraction.

9 See Leland and Pyle (1977).

10 Deadweight losses arise because in theory firms could issue the same options to outside investors. A caveat is that they would clearly not receive the unadorned Black-Scholes values due to the complicating features of executive options such as vesting periods or inalienability.

11 See SWX-Directive on Information Relating to Corporate Governance, p. 24.

12 Note that our analysis includes both executive and non-executive directors because it is also common for the latter group to receive of share options. In 2002, 44.4\% of Swiss firms allotted options to their top management and $27.1 \%$ to their non-executive directors on the board. For aggregate option holdings in our sample, the figures are $56.5 \%$ and $43.5 \%$ for executive and non-executive directors, respectively.

13 Out of the 62 companies with incomplete data, 15 are not covered by Datastream and another 15 are small companies, e.g., mountain railways or public utilities, which have a business year ending other than December and did not provide an annual report that includes the newly required corporate governance section at the time of data collection. The remaining 32 firms were excluded for various reasons. In most cases the annual report was either not available or the section on executive compensation was missing. Most of these 62 companies are very small (with a market capitalization below CHF 100 millions) and still have no option programs in place as of today. Therefore, they would have been excluded from our sample even if data availability was no problem.

14 These options are so called quanto options and cannot be valued using the Black-Scholes (1973) or the HallMurphy (2002) methodology.

15 In results not shown here we find that this assumption does not qualitatively change our empirical results.

16 See Hall und Murphy (2002), p. 9.

17 It is „public knowledge“ that Daniel Vasella, the CEO of Novartis, and Marcel Ospel, the chairman of UBS, earn significantly more than the maximum number (CHF 8,932,520) in table 1 . We do not have access to individualized compensation data and compute averages at the firm level. Therefore, the individualized compensation figures ought to be much more skewed than those presented in table 1. 
18 See Holmström and Tirole (1993), Burkart et al. (1997), and Chidambaran and John (1999) for theoretical work on the interaction between monitoring of managers and incentive compensation. Monitoring in these models is by the stock market, outside investors, and institutional investors, respectively.

19 In our analysis we treat board and ownership structures as exogenous, even though theory would suggest that they are endogenous. However, a crucial problem in empirical work is the choice of proper instrumental variables. Our regression results are potentially affected by a simultaneous equation bias (e.g., see Agarwal and Knoeber, 1996; Himmelberg et al., 1999; Beiner et al., 2006), but weak instruments can lead to a larger inconsistency in the instrumental variables estimate than in the OLS estimate (e.g., Bound et al., 1995).

20 See Börsch-Supan and Köke (2002) for a more general analysis of omitted variables problems in empirical corporate governance research.

21 In unreported tests, we additionally included dummy variables whether the firm is diversified at the 2-digit (4-digit) SIC code level to proxy for the complexity of the firm. However, the coefficients were statistically insignificant while all other results remained basically unchanged.

22 See Smith (1996) and Gillian and Starks (2000) for a more general discussion about shareholder activism of institutional investors.

23 Using Swiss data, Beiner et al. (2006) cannot confirm Yermack’s (1996) finding of an inverse relationship between board size and firm value, as measured by Tobin's Q.

24 Note that the delta of cash and stock are 0 and 1 , respectively. Our results remain unchanged when the optiongrant sensitivity instead of the total pay-for-performance sensitivity is used as the independent variable.

25 While the use of market values as dependent variables may lead to endogeneity problems, this should not be an issue for risk-adjusted values due to changes in the composition of the portfolio of the top 10 percent earners.

26 See already Baker et al. (1988). However, managers may also choose size endogenously through merger and acquisition activities as a takeover deterrent, allowing them to pay higher wages.

27 The empirical results in Smith and Watts (1992) suggest that executive compensation increases with firm risk. According to theory, however, the direction of influence of firm risk on the level of expected compensation is ambiguous (e.g., Banker and Datar, 1989), which may explain why firm risk (Sigma) is estimated insignificantly.

28 A caveat is that our results are subject to the assumptions that there are no omitted economic determinant variables and that ownership and board variables are exogenous. Core et al. (1999) show that the predicted excess compensation based on ownership and board variables is negatively related to subsequent firm performance. This suggests that these variables are proxies for the degree of managerial entrenchment rather than coincidentally picking up misspecifications in the model for the equilibrium level of pay.

29 Calculated as $\mathrm{e}^{1.17}-1 \approx 2.22$. 